\title{
A review of fire management practices in African savanna-protected areas
}

\begin{tabular}{|c|c|}
\hline \multicolumn{2}{|c|}{$\begin{array}{l}\text { Authors: } \\
\text { Willem A. Nieman } \\
\text { Brian W. van Wilgen }{ }^{1,2} \\
\text { Alison J. Leslie }^{1}\end{array}$} \\
\hline \multicolumn{2}{|c|}{$\begin{array}{l}\text { Affiliations: } \\
{ }^{1} \text { Department of Conservation } \\
\text { Ecology and Entomology, } \\
\text { Faculty of AgriSciences, } \\
\text { Stellenbosch University, } \\
\text { Stellenbosch, South Africa }\end{array}$} \\
\hline $\begin{array}{l}{ }^{2} \text { Majete Resea } \\
\text { Programme, } \\
\text { Reserve, Chikv }\end{array}$ & $\begin{array}{l}\text { arch } \\
\text { Majete Wildlife } \\
\text { wawa, Malawi }\end{array}$ \\
\hline \multicolumn{2}{|c|}{$\begin{array}{l}{ }^{3} \text { Centre for Invasion Biology, } \\
\text { Department of Botany and } \\
\text { Zoology, Faculty of Science, } \\
\text { Stellenbosch University, } \\
\text { Stellenbosch, South Africa }\end{array}$} \\
\hline \multicolumn{2}{|c|}{$\begin{array}{l}\text { Corresponding author: } \\
\text { Willem Nieman, } \\
\text { 17688132@sun.ac.za }\end{array}$} \\
\hline \multicolumn{2}{|c|}{$\begin{array}{l}\text { Dates: } \\
\text { Received: } 04 \text { Sept. } 2020 \\
\text { Accepted: } 27 \text { Nov. } 2020 \\
\text { Published: } 15 \text { Feb. } 2021\end{array}$} \\
\hline \multicolumn{2}{|c|}{$\begin{array}{l}\text { How to cite this article: } \\
\text { Nieman, W.A., Van Wilgen, } \\
\text { B.W. \& Leslie, A.J., 2021, } \\
\text { 'A review of fire management } \\
\text { practices in African } \\
\text { savanna-protected areas', } \\
\text { Koedoe 63(1), a1655. https:// } \\
\text { doi.org/10.4102/koedoe. } \\
\text { v63i1.1655 }\end{array}$} \\
\hline \multicolumn{2}{|c|}{$\begin{array}{l}\text { Copyright: } \\
\text { (c) 2021. The Authors } \\
\text { Licensee: AOSIS. This } \\
\text { is licensed under the } \\
\text { Creative Commons } \\
\text { Attribution License. }\end{array}$} \\
\hline \multicolumn{2}{|l|}{ Read online: } \\
\hline 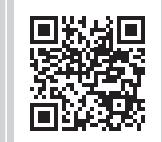 & $\begin{array}{l}\text { Scan this QR } \\
\text { code with your } \\
\text { smart phone or } \\
\text { mobile device } \\
\text { to read online. }\end{array}$ \\
\hline
\end{tabular}

The level of understanding of the ecological effects of fires has improved over the past century, but comprehensive information on the practical application of fire remains restricted to a few well-studied areas, and management information is scattered. This article reviews the goals of fire management practices in African savanna-protected areas, and the approaches that have been adopted to achieve them. We identified 15 distinct fire management practices described in 107 papers from 19 African countries. Fire management has evolved in response to changing ecological understanding, as well as the shifting goals of protected areas. Currently, fire management practices can be divided into those that use fire to achieve specific ecological outcomes, those where fire is applied to promote diverse fire patterns across the landscape without necessarily having a specific ecological outcome in mind, and those that use fire to achieve specific, non-ecological or social goals. In larger, heterogeneous protected areas, fire management practices may vary at different sites in order to achieve a range of goals. We compared the effectiveness of each practice in terms of achieving 10 broad goals. These included ecological goals, for example, reversing woody and social goals (e.g. maintaining community relationships).

Conservation implications: Fire management remains an important ecosystem process that can be manipulated to achieve particular goals in protected areas. The choice of a particular approach, or approaches, will depend on the circumstances pertaining to a particular protected area, and we provide examples of situations where each practice could be most appropriate.

Keywords: biodiversity; bush encroachment; fire regime; global change; grass fuel; $\mathrm{CO}_{2}$-enrichment; environmental management; prescribed burning.

\section{Introduction}

Savannas are characterised by the co-dominance of woody plants and grasses, in which trees that are at least 2 metres $(\mathrm{m})$ tall occur above a grassy layer between $0.5 \mathrm{~m}$ and $2 \mathrm{~m}$ (Scholes \& Walker 1993). Frequent natural fires have historically been reported in African savannas during the dry season, and have played an important role in shaping the composition and structure of these ecosystems (Bond 2019). The importance of fire in maintaining vegetation in savanna is thus well recognised (Archibald et al. 2017), especially in terms of ensuring the continued co-existence of woody and herbaceous plants (Archibald et al. 2013).

Approaches to fire management have evolved over the past century, and some protected areas have undergone multiple changes in fire management over time (Archibald et al. 2017; Van Wilgen et al. 2014). These changes came about in response to increases in understanding of the role and impacts of fire in natural ecosystems, as well as to changing societal needs and increasing challenges associated with global change, including climate change, increasing concentrations of atmospheric $\mathrm{CO}_{2}$ and invasion by alien plants (Bond \& Midgley 2012; Sala et al. 2000). African savannas are dynamic ecosystems, and fire interacts with climatic cycles, varying levels of herbivory, and increasing pressures brought about by rising human populations (Smit \& Archibald 2019). Managers of African savanna-protected areas have to make decisions on the use of fire, including whether, where and how to apply fire, the conditions under which fire should be applied and the goals that such use is intended to achieve. Whilst there is a growing literature on the ecological effects of fire, comprehensive information on the practical application of fire is restricted to a few well-studied areas. The remaining information remains scattered, and a review of the goals of fire management, and the means by which they can be achieved is, therefore, needed. In this research article, we report on a review of the literature relevant to the management of fire in savanna-protected areas in sub-Saharan Africa. The interest of this review is in conservation management, and the purpose of this study was to identify the various goals of fire 
management in protected areas and to review the practices that have been put forward to achieve them. The focus of this review was on studies that dealt with the practical application of fire in African savanna-protected areas, and the assessment of this study was based on these practical applications, and not on the many papers that dealt with the ecological effects of fire, or with the fire management of other African ecosystems, including forests, grasslands and shrublands, or agricultural land uses.

\section{Methods}

A review of the relevant literature was initiated by examining the Scopus and Web of Science databases in April 2020 to identify papers or book chapters published between 1960 and the present (2020) that were relevant to this study. We used the following selection terms in the title, abstract or keywords of the research article: 'Fire' AND 'Africa' AND 'manag*' OR 'prescribed' OR 'policy' OR 'plan' OR 'control' AND 'protected' OR 'reserve' OR 'park' OR 'conserv*'. For all of the papers identified, we read the abstracts and excluded papers that were not relevant to the specific aims of this study (e.g. papers that were not from Africa, papers that did not deal in sufficient detail with fire, papers that dealt with vegetation types other than savannas, papers that were not relevant to protected areas or their management or papers that addressed the ecological effects of fire, but not the management of fire). We then identified additional sources based on the personal knowledge and on references cited in papers identified in the search (these included studies or management plans not covered by Scopus or Web of Science).

For each of the papers that were retained or added, we noted the country where the study was conducted, the goals of fire management, the practices that were implemented or proposed to achieve the goals, the time periods in which the practices were implemented, and the principal findings or recommendations. We used this information to examine how and why management practices changed during the 20th century and beyond, and how different practices were implemented to achieve specific conservation goals.

\section{Ethical consideration}

This article followed all ethical standards for research without direct contact with human or animal subjects.

\section{Results}

\section{Literature identified}

The systematic search revealed 903 papers and book chapters, of which 848 were excluded for one or more of the reasons outlined above. We also identified 52 additional sources, and thus, had a sample of 107 papers based on the review. Papers were sourced from 19 African countries, with over half (58) being from South Africa (Figure 1). Several important early papers arose from a landmark conference dedicated to fire in Africa, which was held at Tallahassee, Florida in 1971, with contributions from 20 authors covering seven African countries in southern, eastern and western Africa (Komarek 1972). Following this, the rate of publication remained below one paper per year until the year 2000, after which there was a steady increase in published studies related to fire management in Africa (Figure 2).

\section{Evolution of fire management}

Fire management has evolved during the past century in response to changing ecological understanding, as well as to the shifting goals of protected areas (Bond \& Archibald 2003;

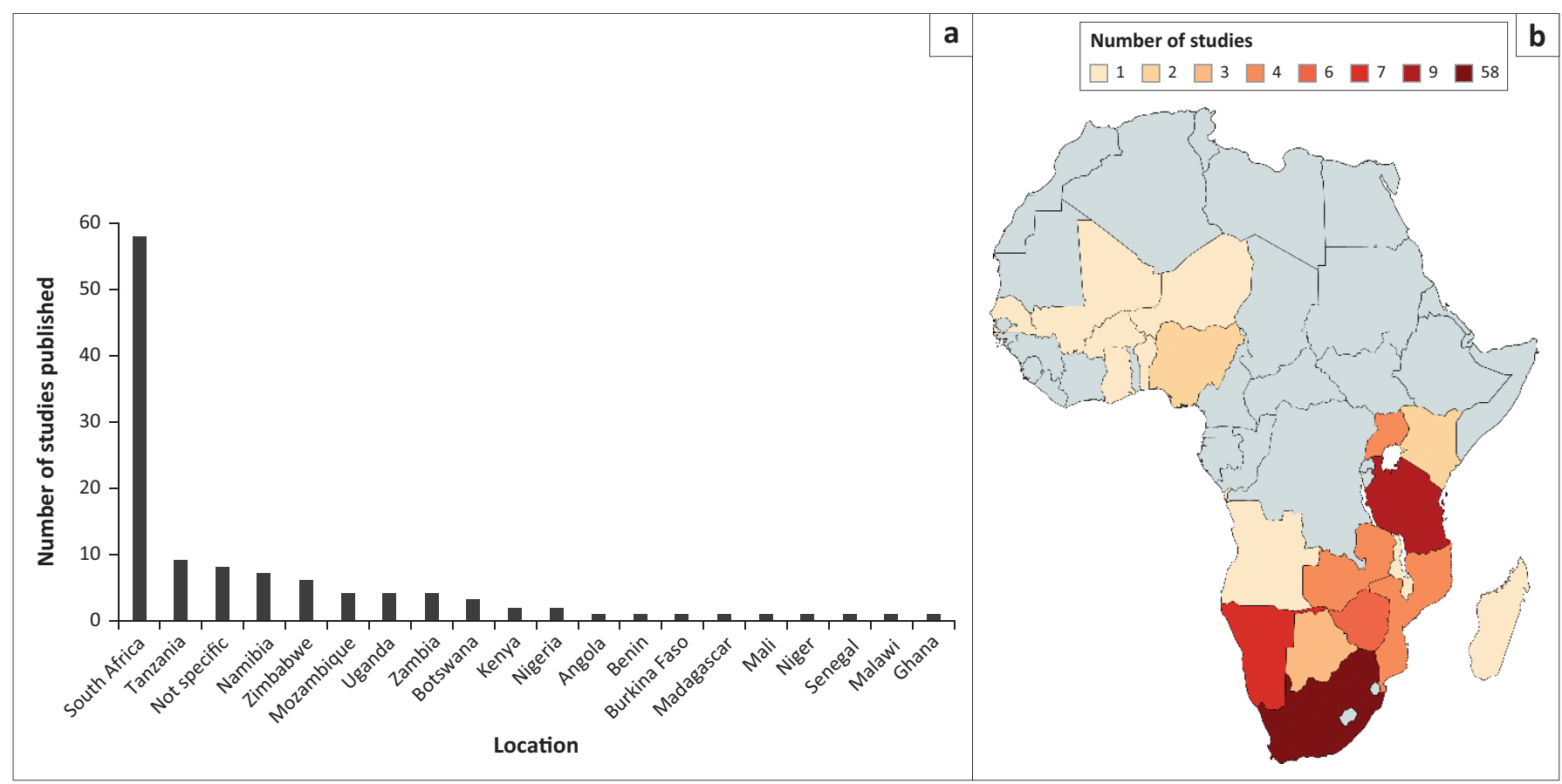

FIGURE 1: Origin of published sources on fire management in African savanna-protected areas. 
Mentis \& Bailey 1990) (Figure 3). In the early 20th century, colonial foresters often influenced the fire policy for large areas of woodland across Africa. Foresters believed that fire prevented vegetation from attaining its full potential ('climax') through succession after disturbance (as set out by Clements 1916), and that it led to landscape degradation in wooded areas (Aubréville 1947; Chipp 1922; Rains 1963; Stebbing 1937). Some examples of interpretations of fire effects in terms of Clements' succession model include regular burning kept savannas in a 'non-climax' (Phillips 1930) or 'sub-climax' (Roux 1969) condition, 'climax' savanna woodlands could persist in the absence of fire

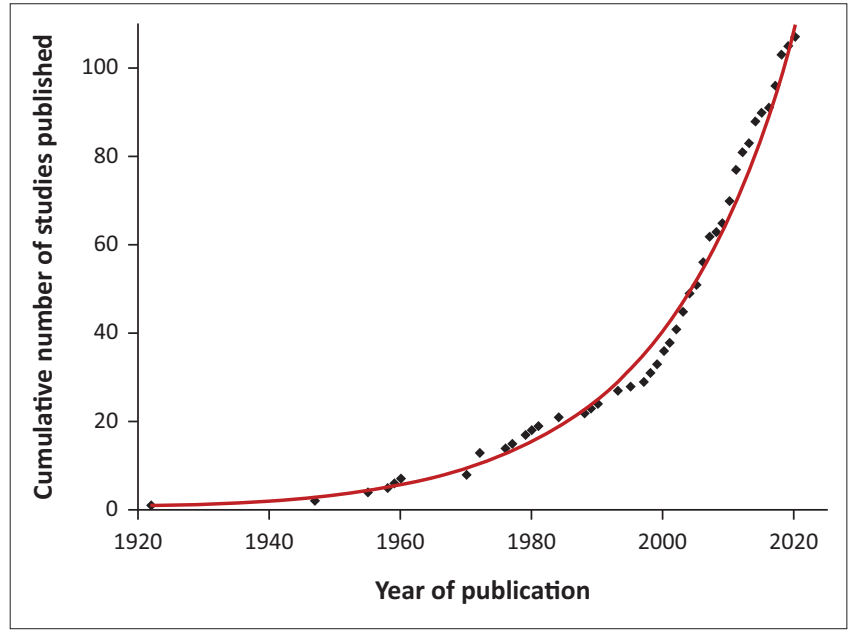

FIGURE 2: The cumulative number of published studies related to fire management in African savanna-protected areas between 1922 and 2020.
(Austen 1972) and climax vegetation was a 'theoretical ideal' towards which savannas would develop in the absence of fire (West 1972).

These interpretations led, in turn, either to attempts to exclude fire or to the promotion of early dry season fires of relatively low intensity that would minimise impacts on trees (Geldenhuys 1977; Laris \& Wardell 2006; Trapnell 1959). Examples include a total ban on fires in Etosha National Park in Namibia (from its establishment in 1907 up to the 1980s) (Stander, Nott \& Mentis 1993), in the Kruger National Park in South Africa (1948-1955) (Joubert 2007), and protection from fire over large parts of Hwange National Park in Zimbabwe in the 1960s and beyond (Austen 1972). In West Africa, fire was regarded as damaging in the early 20th century, and periodic attempts were made to ban fires. However, the inevitability of fire led to the acceptance of early dry season burning in the mid-1950s (Wardell et al. 2004). The policy was underpinned by the findings of burning experiments, which established that early dry season burns would allow trees to regenerate and would also limit the more destructive effects of late dry season fires (Charter \& Keay 1960; Trapnell 1959).

In contrast, the influential ecologist JFV Phillips also noted in 1930 that ' $[c$ controlled firing is a useful and oftentimes necessary agent in veld management' (Phillips 1930). Mid20th century pasture scientists followed this lead, noting that fires played an important role in the management of grassy rangelands (including savannas), serving to remove

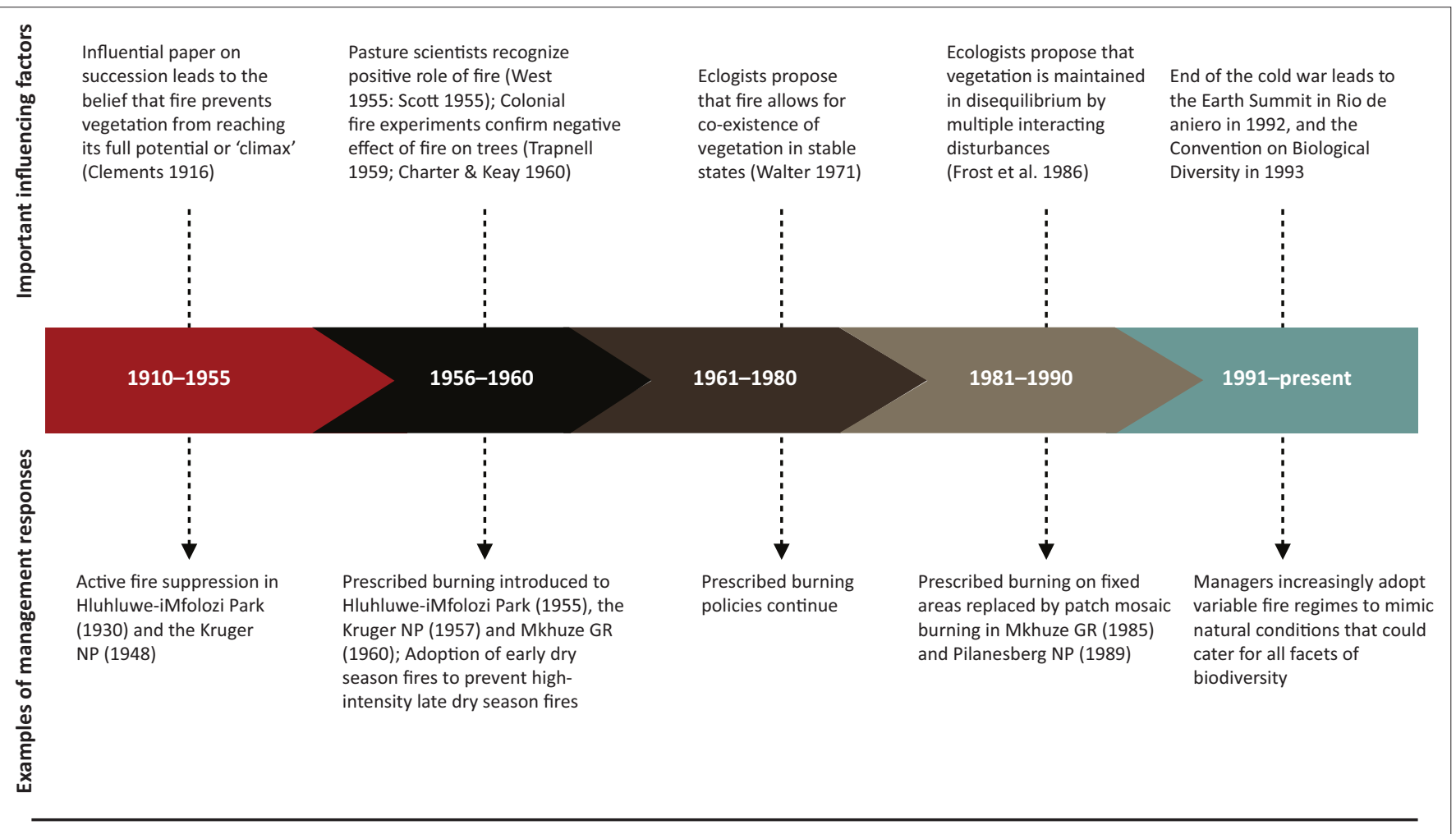

NP, National Park; GR, Game Reserve.

FIGURE 3: Examples of factors that influenced changes in fire management policies and management responses in selected African savanna-protected areas over the past 100 years. 
unpalatable material and rejuvenate the grass sward, as well as retarding encroachment by woody plants (Scott 1955; West 1955). Scott (1955) proposed that early wet season burns (applied in spring after the first rain) would be least harmful to the vegetation. Managers of protected areas thus found themselves conflicted. For example, Austen (1972) noted that 'good forest policy (early burning) is not good wildlife policy', as early burning was less detrimental to trees but encouraged bush encroachment. The recognition that fire was inevitable, and often necessary, led to the increasing adoption of fire as a management practice in many protected areas. In 1955, prescribed burning was initiated in the Hluhluwe-iMfolozi Park, South Africa, inter alia to counter bush increase and to improve visibility for tourists (Vincent 1970). In the Kruger National Park, the application of early wet season fires on a 3-year cycle on fixed areas ('blocks') across the whole park was initiated in 1957 (Brynard 1958). This policy change revealed that fires were both inevitable and ecologically important, and was to stay in place until 'proven incorrect'.

Initially, fire management was aimed at maintaining protected areas in a desired (stable) state by applying fire at regular intervals, in line with ecological theories of equilibrium at the time (Mentis \& Bailey 1990). These theories predicted that grass-tree coexistence was possible, for example, because of niche separation in the rooting depths of grasses and trees that allowed differential access to water in shallow and deeper layers of the soil (Walter 1971), and that a range of stable states were possible (Scholes \& Archer 1997). Ecologists subsequently developed disequilibrium models, which suggested that stable states could not exist, and that wet and dry climatic cycles, fluctuating levels of grazing and browsing, and differences in fire frequency and intensity all combined to continually change the relative mix of grasses and trees (Mentis \& Bailey 1990; Scholes \& Archer 1997). This led to the encouragement of more variability in the application of fire.

A growing recognition of the importance of biodiversity also influenced fire management in the later 20th century. The Convention on Biological Diversity entered into force on 29 December 1993 and was initially signed by 168 countries. Member countries undertook, as per Article 8, to establish and manage protected areas that could maintain viable populations of all species. Managers of African savannaprotected areas began to shift their focus from creating forage for large mammals or protecting trees to catering for the needs of all species. Given the lack of scientific evidence to underpin the formulation of appropriate fire regimes, managers opted for variable fire regimes that would presumably mimic natural processes and provide a wide range of conditions to support all facets of biodiversity. One such approach was patch mosaic burning, which was initially developed in Australia (Saxon 1984) and which aims to create diversity in all elements of the fire regime (Brockett, Biggs \& Van Wilgen 2001; Parr \& Brockett 1999). The approach assumes that spatial and temporal heterogeneity in fire patterns will promote biodiversity conservation. A policy of patch-mosaic burning was implemented in Mkhuze Game Reserve in 1985 (Mulqueeny, Goodman \& O'Connor 2010), in Pilanesberg National Park in 1989 (Brockett et al. 2001) and in the Kruger National Park in 2005 (Van Wilgen, Govender \& MacFadyen 2008). Siegfried (1981) also noted that 'a primary objective of a fire-management strategy for a nature reserve should be an imitation of the local natural fire regime'. This reasoning led to the adoption of policies of deliberately burning to simulate lightning-ignited fire patterns in Etosha National Park in 1985, Du Plessis (1997), or sought to restrict all fires to those ignited by lightning (in the Kruger National Park in 1999, Biggs \& Potgieter 1999). In the early 1990s, the Kruger National Park also adopted adaptive management as an overarching framework to guide all of its activities, including fire management (Van Wilgen \& Biggs 2011). Van Wilgen, Biggs and Potgieter (1998) proposed a set of thresholds of potential concern (TPCs) in which upper and lower limits were defined for the area burnt, and the distribution of fire seasonality, size and intensity. Variability in fire patterns was thus tolerated within limits, and if any TPC was exceeded, then either the management approach could be altered or the threshold could be recalibrated (Biggs $\&$ Rogers 2003). There was little in the way of scientific evidence to guide the degree of variability in fire regimes required to conserve biodiversity in any of these policies (Parr \& Andersen 2006), and the approaches were essentially an insurance policy designed to capture enough variability in fire regimes as might be necessary to cater for all species.

In the 21st century, technological approaches such as remote sensing and fire behaviour prediction models have been increasingly proposed to support the implementation of prescribed burns. For example, it was suggested that remotely sensed estimates of herbaceous biomass (Verbesselt et al. 2006) or fuel moisture content (Verbesselt et al. 2007) could be used to evaluate fire danger, and subsequently assist managers in the identification of areas and timings for prescribed burning. Similarly, real-time monitoring of vegetation biomass with National Oceanic and Atmospheric Administration-Advanced Very High Resolution Radiometer (NOAA-AVHRR) has been proposed for use in arid ecosystems, such as the Etosha National Park (Sannier, Taylor \& Du Plessis 2002) and the Tswalu Kalahari Reserve, South Africa (Tokura et al. 2018), to assist prescribed burning as a form of adaptive fire management.

Fire management has historically been adjusted in individual protected areas several times as understanding developed, but there are few well-documented accounts of these multiple changes outside of South Africa. Changing fire policies are well recorded for the Kruger National Park (Biggs \& Potgieter 1999; Joubert 2007; Van Wilgen et al. 2014) and the HluhluweiMfolozi Park (Archibald et al. 2017; Vincent 1970). In the Serengeti National Park in Tanzania, fires were essentially tolerated for decades before a formal fire management plan 
was adopted. In the Serengeti, Norton-Griffiths (1979) noted that sources of ignition included lightning, fires ignited by pastoralists, honey-hunters and poachers, and that park wardens used fires to make it easier to apprehend poachers and honey-hunters. In 1988, a fire management plan was adopted for the Serengeti, with the aim of reducing the impact of fire on regenerating woodlands, preventing large fires in the late dry season and improving visibility in tourist areas (Stronach 1988). In the following sections, we discuss the approaches that have been adopted to achieve broad management goals.

\section{Broad categories of fire management}

Fire can be manipulated to achieve a wide range of goals in protected areas, and these goals can be divided into three broad categories: Firstly, fire is used to achieve specific ecological outcomes, where fire is applied at a particular frequency, season or intensity, or where fire is intentionally avoided or supressed to directly influence clearly identified aspects of vegetation structure and composition. Secondly, fire is applied to promote a diversity of fire patterns across the landscape (e.g. a mosaic of fire return periods, seasons, intensities and sizes), without necessarily having a specific ecological outcome in mind. The rationale for such approaches has been either that diversity would promote the continued co-existence of co-occurring species that differed in their response or tolerance to elements of the fire regime, or, alternatively, that diversity would mimic natural variations that would have occurred in the absence of human interference. Thirdly, fire is used to achieve specific goals that are non-ecological or social in nature, and these include issues relating to safety or other human benefits (Table 1). Each of these broad categories is discussed below.

\section{Fire management to achieve specific ecological outcomes}

\section{Reducing tree mortality}

Up to the mid-20th century, the practice of not using fire, or actively suppressing any fires that may occur, was widely promoted to reduce the putative negative effects of fire, especially on large trees, or to allow for the development of climax vegetation (West 1972). These fire protection policies were common across African savanna areas (Bond \& Archibald 2003; Du Plessis 1997; Egunjobi 2018; Laris \& Wardell 2006; Pricope \& Binford 2012), but these largely failed to achieve their intended purpose, as large fires persisted despite fire suppression (Biggs \& Potgieter 1999; Pricope \& Binford 2012). Additionally, fire suppression may lead to an increased bush encroachment, particularly when coupled with overgrazing, as shown in Madikwe Game Reserve, South Africa (Hudak et al. 1998, 2004). Fire suppression policies have, therefore, become largely outdated, but some countries, particularly in west Africa (Eriksen 2007; Goldammer \& De Ronde 2004), remain opposed to fire. In more recent years, managers wishing to reduce tree mortality rates or promote tree recovery (especially in miombo woodlands, Ryan \& Williams 2011) opted for low-intensity, early dry season fires under mild weather conditions (Govender et al. 2006; Ribeiro et al. 2017; Smit et al. 2016), or for reduced fire frequencies (especially in areas with high elephant densities; Eckhardt et al. 2000).

\section{Improve forage quality and remove moribund or unpalatable grass material}

Burning to improve forage quality (i.e. range condition), or to remove moribund or unpalatable grass for the benefit of grazers, usually requires managers to base their decision of whether to burn on the species composition and biomass of the grass sward (Bond \& Archibald 2003; Van Wilgen et al. 2003). The main goal is often not necessarily to improve range condition but to encourage uniform grazing, and to decrease unpalatable grasses and bare ground patches. As a result, the forage quality for wildlife is improved, thus enabling larger numbers of grazing animals to be supported. A balanced woody to grass ratio is also established, and wildlife is encouraged to move to less preferred areas in order to prevent overutilisation (Edwards 1984; Trollope 2007). In order to achieve these goals, burning can take place either (1) in the early dry season to produce a flush of green grass regrowth or (2) in the early wet season to remove moribund grass that remains after the dry season with minimal damage to the grass sward (Scott 1955; Trollope 2007). Burning in the early dry season would force grasses to regrow through the dry season without the benefit of moisture, thus removing forage that could sustain grazing mammals through the dry season (Archibald et al. 2017; Scholes \& Walker 1993). Fires in either the early dry or early wet season need to be of sufficient intensity to avoid bush encroachment (O'Connor, Puttick \& Hoffman 2014). Areas of relatively high rainfall (> 650 millimetres [mm] MAP) can usually be burnt more regularly, but in more arid sites fire should only be applied in years when the grass biomass is unusually high, normally following a period of aboveaverage rainfall, and when the grass species composition warrants the use of fire to remove unpalatable species (Trollope et al. 2014).

\section{Reverse woody encroachment}

In instances where the density of woody plants has increased to undesirable levels, relatively high-intensity fires can be used to reverse woody encroachment and limit tree recruitment (Ryan \& Williams 2011; Smit et al. 2016; Van Wilgen et al. 2014). High-intensity fires can also have unintended consequences, such as increased mortality rates of very large trees (Govender et al. 2006; Smit et al. 2016), compromising the safety of burning crews (Kamminga 2001), and increasing greenhouse gas emissions (Van Der Werf et al. 2010). The effect of high-intensity fires on tree mortality is also more pronounced in drier ecosystems (Holdo 2005), in years when grass fuels are high (Govender et al. 2006), and in miombo woodlands, where they inhibit the natural regeneration of miombo trees (Ribeiro et al. 2017). Burning in the late dry season is, therefore, not widely used, although it has been shown to be effective in reducing the cover of shrubs on an experimental basis in the Kruger 
TABLE 1: Fire management goals and associated practices that have been proposed, or are used, for the management of fire in African savanna-protected areas.

\begin{tabular}{ll}
\hline Fire management category & Specific goals \\
\hline Fire management to & Improve forage quality \\
achieve specific & for the benefit of large \\
ecological outcomes & $\begin{array}{l}\text { grazing mammals and } \\
\text { remove moribund or } \\
\text { unpalatable grass } \\
\text { material }\end{array}$
\end{tabular}

Reverse the encroachment of woody plants

Reduce tree mortality ntion and suppression or early dry season burns of low intensity, reduction of fire frequency Fire management practice Instances where the specific goal and practice have been reported

Apply burns in the early wet South Africa (Bond \& Archibald 2003; Edwards 1984; Scott 1955)

season, base the decision to burn Southern Africa (Trollope 2007)

on grass sward composition and Kruger NP, South Africa (Biggs \& Potgieter 1999; Brynard 1972; Trollope et al. 1995

2014; Van Wilgen et al. 2003)

Serengeti NP, Tanzania (Eby et al. 2015)

Kasanka NP, Zambia (Eriksen 2007)

Madrid Game Ranch, South Africa (Gureja \& Owen-Smith 2002)

Nylsvley NR, South Africa (Scholes \& Walker 1993)

Okavango Delta, Botswana (Trollope et al. 2006)

Majete WR, Malawi (Nieman 2020)

Kruger NP, South Africa (Smit et al. 2016)

Hluhluwe-iMfolozi Park, South Africa (Archibald et al. 2017; Balfour \& Howison 2001

Browne \& Bond 2011; Case \& Staver 2017; Vincent 1970)

South Africa (Bond \& Archibald 2003)

Madikwe GR, South Africa (Hudak 1999; Hudak, Brockett \& Wessman 1998)

Southern Africa (Messina et al. 2018)

Mkhuze GR, South Africa (Mulqueeny, Goodman \& O'Connor 2011)

Mokopane WR, South Africa (Munyati, Shaker \& Phasha 2011)

Okavango Delta, Botswana (Trollope et al. 2006)

Zambia (Trapnell 1959)

Caprivi, Namibia (Geldenhuys 1977)

West and Central Africa (Aubréville 1947)

Hwange NP, Zimbabwe (Austen 1972)

Kruger NP, South Africa (Eckhardt, Van Wilgen \& Biggs 2000; Smit et al. 2016)

Nigeria (Egunjobi 2018)

Soudan Savanna belt, Mali (Laris \& Wardell 2006)

Niassia NR, Mozambique (Govender, Trollope \& Van Wilgen 2006; Ribeiro et al. 2017)

Kidepo Valley NP, Uganda (Ross, Field \& Harrington 1976)

Zimbabwe (West 1972)

Olokemeji FR, Nigeria (Charter \& Keay 1960)

Kavango, Namibia (Geldenhuys 1977)

South Africa (Scott 1955)

Serengeti NP, Tanzania (Stronach 1988)

Kavango-Zambezi TCA (Pricope \& Binford 2012)

Control invasive alien Fire must be applied in different plants the invasive species involved

Protect fire-sensitive species or habitats vulnerable to fire

Protect specific areas using firebreaks, or burn surrounding areas in low-intensity fires; no deliberate burning

Control disease vectors Any fire (mainly ticks)

Fire management to promote diverse fire patterns

Promote a diverse

Patch mosaic burning fire regime

Promote a fire regime that mimics natural conditions

Reduce the extent of late dry season burns

Fire management to promote non-ecological or social goals
Protection of

infrastructure

Reduce greenhouse gas emissions and conserve carbon stocks

Allow pre-fire harvesting of thatch grasses earlier in the dry season

Avoid conflict with local communities
Allow lightning fires to burn unhindered, deliberate burning to simulate natural (lightning-driven) fire regimes

Burning in the early dry season; patch mosaic burning

Protect specific areas using firebreaks or low-intensity fires

Early dry season burns

Postpone any burns to the late dry or early wet season

Align fire management interventions with traditional practices
Hluhluwe-iMfolozi Park, South Africa (Dew et al. 2017; Te Beest et al. 2012. Te Beest, Mpandza \& Olff 2015)

Serengeti NP, Tanzania (Bukombe et al. 2018)

Marondera RS, Zimbabwe (Masocha et al. 2011)

Serengeti NP, Tanzania (Eby et al. 2015; Stronach \& McNaughton 1989)

Limpopo Province, South Africa (Pfab \& Witkowski 2000)

Murchison Falls NP, Uganda (Nangendo et al. 2005)

Ngorongoro Crater, Tanzania (Fyumagwa et al. 2007; Trollope, Fyumagwa \& Trollope 2003) Madikwe WR, South Africa (Goodenough et al. 2017) Serengeti NP, Tanzania (Eby et al. 2015)

Sioma-Ngwezi NP, Zambia (Trollope \& Trollope 2010)

West Africa (Laris \& Wardell 2006)

Pilanesberg NP, South Africa (Brockett et al. 2001)

Mkhuze GR, South Africa (Mulqueeny et al. 2010)

Southern Africa (McGranahan \& Kirkman 2013)

South Africa (Mentis \& Bailey 1990; Van Wilgen 2009)

Hluhluwe-iMfolozi Park, SA (Archibald et al. 2017; Balfour \& Howison 2001)

Kruger NP, South Africa (Biggs \& Potgieter 1999; Parr, Woinarski \& Pienaar 2009;

Smit et al. 2013; Van Wilgen et al. 2003, 2014; Van Wilgen, Govender \& Biggs 2007)

Smit et al. 2013; Van Wilgen et al. 2003, 2014; Van Wilgen,
North-West Province, South Africa (Docherty et al. 2020)

North-West Province, South Africa

Soudan savanna belt, Mali (Laris \& Wardell 2006)

Budongo FR, Uganda (Nangendo et al. 2005; Nangendo, Ter Steege \& Bongers 2006) Africa (Parr \& Andersen 2006)

Etosha NP, Namibia (Du Plessis 1997; Siegfried 1981; Stander et al. 1993)

Kruger NP, South Africa (Biggs \& Potgieter 1999; Trollope et al. 1995; Van Wilgen et al. 2003, 2007)

Madikwe GR, South Africa (Hudak, Fairbanks \& Brockett 2004)

South Africa (Van Wilgen 2009)

Zambia (Trapnell 1959)

Hwange NP, Zimbabwe (Austen 1972)

Pilanesberg NP South Africa (Brockett et al. 2001)

Serengeti NP, Tanzania (Owen 1972)

Kruger NP, South Africa (Van Wilgen et al. 2014)

Serengeti NP, Tanzania (Eby et al. 2015)

Niassa NR, Mozambique (Ribeiro et al. 2017)

Majete WR, Malawi (Nieman 2020)

Africa (Lipsett-Moore, Wolff \& Game 2018)

Zimbabwe and Mozambique (Ryan \& Williams 2011)

Sioma-Ngwezi NP, Zambia (Trollope \& Trollope 2010)

West Africa (Hough 1993)

Hluhluwe-iMfolozi Park, South Africa (Archibald et al. 2017)

Majete WR, Malawi (Nieman 2020)

Soudan savanna Belt, Mali (Laris \& Wardell 2006)

Southern Africa (Moura et al. 2019)

Chyulu Hills NP, Kenya (Kamau \& Medley 2014)

Kasanka NP, Zambia (Eriksen 2007)

Sub-Saharan Africa (Goldammer \& De Ronde 2004)

West Africa (Hough 1993)

Ankarafantsika NR, Madagascar (Kull 2002)

Kavango-Zambezi TCA (Pricope \& Binford 2012)

Zimbabwe and Mozambique (Ryan \& Williams 2011)

Matutuine District, Mozambique (Shaffer, Hall \& Street 2010) 
TABLE 1 (Continues ...): Fire management goals and associated practices that have been proposed, or are used, for the management of fire in African savanna-protected areas.

\begin{tabular}{|c|c|c|c|}
\hline Fire management category & Specific goals & Fire management practice & Instances where the specific goal and practice have been reported \\
\hline \multirow[t]{2}{*}{$\begin{array}{l}\text { Fire management to } \\
\text { promote non-ecological } \\
\text { or social goals }\end{array}$} & $\begin{array}{l}\text { Improve visibility for } \\
\text { tourism and for effective } \\
\text { policing }\end{array}$ & Any fire & $\begin{array}{l}\text { Umfolozi GR, South Africa (Vincent 1970) } \\
\text { Serengeti NP, Tanzania (Eby et al. 2015; Stronach 1988) } \\
\text { Madikwe GR, South Africa (Hudak 1999) }\end{array}$ \\
\hline & $\begin{array}{l}\text { Avoid using scarce } \\
\text { resources to manage a } \\
\text { process that is not } \\
\text { harmful }\end{array}$ & $\begin{array}{l}\text { Laissez faire - allow any fires that } \\
\text { may occur to burn unhindered. }\end{array}$ & $\begin{array}{l}\text { Niassa NR, Mozambique (Ribeiro et al. 2017) } \\
\text { Kruger NP, South Africa (Govender, Mutanga \& Ntsala 2012; Van Wilgen et al. 2014) } \\
\text { South Africa (Bond \& Archibald 2003) }\end{array}$ \\
\hline
\end{tabular}

NP, National Park; GR, Game Reserve; FR, Forest Reserve; NR, Nature Reserve; TCA, Transfrontier Conservation Area; RS, Research Station; WR, Wildlife Reserve.

National Park (Smit et al. 2016) and has been included in the fire management plan of the Okavango Delta Ramsar Site (Trollope et al. 2006). Fires in the late dry season nonetheless remain illegal or are actively discouraged in many African countries, particularly in West Africa (Laris \& Wardell 2006). Early wet season fires can also reverse woody encroachment, provided that grass fuel loads are high enough to support a relatively high-intensity fire (see, e.g., Crowley, Garnett \& Shephard 2009).

\section{Control invasive alien plants}

Invasive alien plants are a substantially growing problem in protected areas (Foxcroft et al. 2013), including African savannas (Te Beest et al. 2012; Van Wilgen et al. 2017; Witt et al. 2017), and fire is often involved in both their spread and their management (Dew et al. 2017). Fires of high intensity can be used to clear invasive alien plants and reduce their seedling densities (Te Beest et al. 2012). Te Beest et al. (2017) suggested that frequent fires of high intensity would be necessary to control the invasive alien shrub Chromolaena odorata. Similarly, Bukombe et al. (2018) found that alien species were more abundant in areas with infrequent or no fires. Fires, however, also open up the landscape, providing opportunities for alien species to establish (Te Beest et al. 2015), and a deliberate reduction in fire frequency has, therefore, been suggested for some protected areas to limit the colonisation potential of alien invasive species. This applies especially to mesic savannas, where alien forbs readily establish on disturbed areas (Masocha et al. 2011). Because responses to fire are species-specific, a species-specific approach to managing alien invasions would be required.

\section{Protect rare or fire-sensitive species or habitats}

Within protected areas, fires may be excluded from the habitats of rare or fire-sensitive animal species, such as reptiles, rhinoceros and nesting birds (Eby et al. 2015), or vegetative communities to maintain their presence in the landscape, such as regenerating woodlands, tree copses, rocky hill vegetation, forests, and thickets (Eby et al. 2015; Nangendo et al. 2005; Pfab \& Witkowski 2000; Stronach \& McNaughton 1989). Furthermore, in many African-protected areas, forest, woodland and savanna vegetation types coexist, and fire management should accommodate this variation. For example, Nangendo et al. (2006) proposed that forest landscapes in the Budongo Forest Reserve, Uganda, should not be burned, whilst the adjacent wooded grassland should be burnt regularly. Similarly, a variety of approaches were recommended for Murchison Falls National Park, Uganda, because of the large variety of vegetation types (Nangendo et al. 2005). Te Beest et al. (2012) recommended selective fire suppression in riverine vegetation and margins of scarp forests to protect fire-sensitive endemic species. Excluding fires from selected areas is, however, difficult in protected areas that are prone to unplanned fires, or that have limited resources to manage fires (Nangendo et al. 2005).

\section{Control disease vectors}

Fire can be a useful tool for controlling an array of disease vectors. It is most commonly used for controlling ticks (Acari: Ixodidae), which may cause wildlife mortalities when excessively abundant (Trollope et al. 2003). Numerous studies have validated this approach by demonstrating a decline in tick abundance for up to 3 years after a fire (Fyumagwa et al. 2007; Goodenough et al. 2017). Tick numbers not only are reduced by the actual fire but also remain low long after the fire because of less abundant grass (Trollope et al. 2003). Similarly, managers of protected areas have used fire to reduce the risk of exposure to African trypanosomiasis (sleeping sickness) by reducing the incidence of tsetse flies (Glossina spp.) (Eby et al. 2015).

\section{Fire management to promote diverse fire patterns}

In the past three decades, the importance of heterogeneous fire patterns (i.e. pyrodiversity) to accommodate all facets of biodiversity has increasingly been highlighted as an important management consideration (Parr \& Andersen 2006), resulting in attempts to promote diverse fire regimes in many savanna-protected areas. The promotion of pyrodiversity is believed to provide an array of habitats through space and time, which should allow biota with different life histories to coexist at the landscape scale (Beale et al. 2018). These policies, known as patch mosaic burning, aim to create heterogeneity in fire distributions, size classes, return intervals, seasons and intensity (Brockett et al. 2001; Mentis \& Bailey 1990). The reported outcomes of patchmosaic burning policies implemented in South Africanprotected areas (Archibald et al. 2017; Balfour \& Howison 2001; Brockett et al. 2001; Mulqueeny et al. 2010) most often include a shift in a more even distribution of fires over the dry season, an increase in the number of fires and a reduction in mean fire sizes because of the breaking up of continuous grass fuels in relatively small early dry season burns. Both increased fire frequencies (Mulqueeny et al. 2010) and spatial heterogeneity (Brockett et al. 2001) have also resulted from these approaches in smaller $(<100000$ hectares [ha]) protected areas. In larger protected areas, managers have been able to manipulate the spatial heterogeneity of fires, but fire return 
periods were correlated with annual rainfall rather than by management interventions (Van Wilgen et al. 2004).

The majority of fires reported in African savanna-protected areas often occur during the late dry season as unplanned wildfires (Lipsett-Moore et al. 2018) because fires are ignited outside of protected areas (Eriksen 2007). Fires in the early dry season are thus widely considered to be the only practical means to prevent wildfires in the late dry season by breaking up of continuous fuel beds (Owen 1972), and patch mosaic burning could achieve this goal by igniting fires in the early dry season.

Patch burning is sometimes closely associated with natural fire policies and has been implemented as a hybrid system in the Kruger National Park (Van Wilgen et al. 2014). The promotion of a natural fire regime is based on the belief that 'nature knows best' (Siegfried 1981; Van Wilgen et al. 1998), and human interference should thus be kept to a minimum. Implementing a natural fire regime thus entails allowing all fires ignited by lightning to spread unhindered, whilst suppressing any fires ignited by human beings. This policy was, however, abandoned in the Kruger National Park after 10 years of implementation, when it became apparent that it was unworkable, because the vast majority of the area continued to be burnt by fires ignited by people (Van Wilgen \& Biggs 2011). The Etosha National Park in Namibia sought to replicate lightning fire patterns by applying prescribed burns to selected areas that had received above-average rainfall in the preceding year and by limiting burning to $<12 \%$ of the protected area (Du Plessis 1997; Stander et al. 1993). Fires should be applied in the early wet season, as this is thought to mimic a fire regime that would have been driven by lightning storms (Goldammer \& De Ronde 2004).

\section{Fire management to promote non-ecological or social goals}

\section{Greenhouse gas emissions and carbon stocks}

Global emissions from wildfires (mainly methane $\left[\mathrm{CH}_{4}\right]$ and nitrous oxide $\left[\mathrm{N}_{2} \mathrm{O}\right]$ ) (Landry \& Matthews 2016) have become a cause of concern in recent years (Van Der Werf et al. 2017). It has thus been proposed that burning in the early dry season in Africa's protected areas could offer an opportunity to reduce these gas emissions. A switch from late to early dry season fires can potentially reduce gas emissions by as much as 37\% (64.2 $\mathrm{MtCO}_{2}-\mathrm{e} \mathrm{yr}^{-1}$ ) (Lipsett-Moore et al. 2018; Russell-Smith et al. 2013). Simultaneously, this could provide stakeholders in protected areas with substantial revenue from the Green Climate Fund (Green Climate Fund [GCF] Pilot Programme 2017). For this effect to become apparent, however, grass fuels will have to be fully cured before burning occurs, as moist grass would produce smoldering fires with enhanced $\mathrm{CH}_{4}$ and carbon monoxide (CO) emissions (Meyer et al. 2012).

\section{Avoiding conflict with local communities}

Most protected areas in African savannas exist in close proximity to indigenous communities, and often, the responsibility for land management is shared by conservation and local authorities. Conflicts may arise between the two if an appropriate approach to fire management is not agreed upon (Laris \& Wardell 2006; Moura et al. 2019). Local communities may consider regular burning in the early dry season to be necessary for, inter alia, improving both pasture and hunting landscapes, clearing fields for crops, or preventing destructive fires later in the dry season (Eriksen 2007; Laris \& Wardell 2006), whilst the conservation goals of protected areas may not be aligned with this (Eriksen 2007; Laris 2002). In instances where fire policies were implemented without due consideration of the resource needs and traditional beliefs of local communities, large-scale illegal burning has occurred in retaliation (Hough 1993; Kull 2002). For example, Kamau and Medley (2014) listed 'protest against the Kenya Wildlife Service' as a reason given by communities for burning, whilst Laris and Wardell (2006) noted that West African communities were 'setting fires covertly and as a form of protest' against punishment for practising traditional burning. It is thus often necessary for managers of protected areas and representatives of local communities to work together to design appropriate fire regimes that incorporate modern conservation goals and traditional practices (Kamau \& Medley 2014; Moura et al. 2019; Shaffer etal. 2010) in order to avoid alienating indigenous communities (Eriksen 2007). This will likely result in increases in fires in the early dry season, which may placate local communities, as well as reduce greenhouse gas emissions (Moura et al. 2019). However, in instances where local communities are permitted to collect resources (most often thatch grass, but also bamboo, reeds and medicinal plants) from protected areas, fires may have to be postponed until the late dry season to provide access to thatch grass and other subsistence goods that need to be collected before burning (Hough 1993; Nieman 2020), which may prevent managers from planning fire regimes to achieve desired goals (Archibald et al. 2017). Substantial progress has been made in connecting local communities and protected area managers through the development of community-based fire management and integrated fire management concepts during the late 1990s (Goldammer \& De Ronde 2004; Pricope \& Binford 2012).

\section{Additional non-ecological goals}

Low-intensity fires in the early dry season are more easily controlled than high-intensity fires in the late dry season, and managers, therefore, often prefer applying prescribed fires in the early dry season to promote the safety of people, wildlife and infrastructure (Kamminga 2001). Fires may also be entirely excluded from areas with high human population or infrastructure density by establishing firebreaks before the onset of the fire season (Nieman 2020), and in the HluhluweiMfolozi Park, active fire suppression was practised to prevent fires from destroying Harris traps that were used to reduce populations of tsetse flies (Archibald et al. 2017). In addition, in order to enhance tourist experiences, managers may use fires to improve visibility for game viewing or to minimise large, unattractive burnt areas by applying 
low-intensity burns in the early dry season (Eby et al. 2015; Hudak 1999; Nieman 2020). Likewise, managers may use fires to create conditions for effective policing, such as burning areas with high poaching incidence, or where there are security concerns, to improve visibility and accessibility (Eby et al. 2015). Finally, in order to avoid wasting scarce resources, managers may simply allow fires to burn unhindered (laissez faire) in cases where there is no evidence to suggest detrimental effects on ecosystems, or where there is insufficient capacity to implement alternative approaches. Ribeiro et al. (2017) recommended this approach in areas reported with high frequency of fire to allow for healthy persistence of the vegetation (3-4 years). Riparian zones in the Kruger National Park are also simply allowed to burn in infrequent fires (Van Wilgen et al. 2014).

\section{Discussion}

\section{Options for fire management}

This review has confirmed the widespread use of fire in the management of savannah-protected areas in Africa, reflecting on a growing body of research to evaluate past fire management approaches and to make proposals for novel ways to manage fire in the face of global change. Although a number of fire management approaches have become largely outdated (e.g. fire suppression policies), and novel methods of monitoring fires (e.g. remote sensing) have improved the ability to monitor and understand fire, there is still little consensus on a broad fire management approach that would adequately cater for different ecological or societal circumstances. This can leave managers without clear guidelines for implementing appropriate fire regimes, especially in the face of unprecedented global change. The seven distinct fire management approaches identified here have been used to achieve 10 ecological and socio-economic goals that were sometimes confined to specific time periods and locations (Table 2). Application of fires in the early dry and wet season fires is arguably the most practical approach for balancing both ecological (e.g. maintaining good range condition and controlling disease vectors) and societal (e.g. maintaining good relationships with communities and promoting safe burning conditions) goals, and is thus appropriate for an array of savanna-protected areas, particularly those that are heavily influenced by local communities. Conversely, whilst application of fires in the late dry season may provide the same ecological and social benefits as early dry or early wet season regimes, they can compromise the safety of people, wildlife and infrastructure (Kamminga 2001), and are, therefore, normally only considered for use in protected areas with exceedingly high levels of woody encroachment. Fires in the late dry season may also be useful for controlling invasive alien plants (Te Beest et al. 2012), but specific guidelines need to be developed for the alien species concerned. Fire exclusion would protect tall trees (Eckhardt et al. 2000), but would be costly and impractical for most fire-prone African savanna-protected areas (Berry \& Macdonald 1979). Fire exclusion may nonetheless be suited for the protection of discrete firesensitive habitats within protected areas (Eby et al. 2015). Natural, lightning-driven regimes are similarly difficult to maintain because of the influence of human ignitions, but can be simulated in large protected areas. Patch-mosaic burning regimes, in contrast, are more ideally suited for smaller (<100 000 ha) protected areas; however, Brockett et al. (2001)

TABLE 2: Goals of fire management in African savanna-protected areas, with an assessment of the suitability of different practices for achieving the goal concerned.

\begin{tabular}{|c|c|c|c|c|c|c|c|c|c|c|c|}
\hline \multirow{2}{*}{$\begin{array}{l}\text { Fire } \\
\text { management } \\
\text { practice }\end{array}$} & \multicolumn{10}{|c|}{ Goal of management } & \multirow{2}{*}{$\begin{array}{l}\text { Situations where the } \\
\text { practice would be } \\
\text { appropriate }\end{array}$} \\
\hline & $\begin{array}{l}\text { Protect } \\
\text { large } \\
\text { trees }\end{array}$ & $\begin{array}{c}\text { Maintain } \\
\text { optimal range } \\
\text { condition }\end{array}$ & $\begin{array}{c}\text { Reverse } \\
\text { woody } \\
\text { encroachment }\end{array}$ & $\begin{array}{c}\text { Maintain all } \\
\text { facets of } \\
\text { biodiversity }\end{array}$ & $\begin{array}{c}\text { Control } \\
\text { invasive alien } \\
\text { plants }\end{array}$ & $\begin{array}{l}\text { Control } \\
\text { disease } \\
\text { vectors }\end{array}$ & $\begin{array}{l}\text { Protection } \\
\text { and safety }\end{array}$ & $\begin{array}{c}\text { Reduce } \\
\text { greenhouse } \\
\text { gas emissions }\end{array}$ & $\begin{array}{c}\text { Maintain } \\
\text { community } \\
\text { relationships }\end{array}$ & $\begin{array}{c}\text { Harvest } \\
\text { natural } \\
\text { resources }\end{array}$ & \\
\hline $\begin{array}{l}\text { Early dry } \\
\text { season burns }\end{array}$ & $\checkmark$ & $\checkmark$ & $<>$ & $x$ & ? & $\checkmark$ & $\checkmark$ & $\checkmark$ & $\checkmark$ & $x$ & $\begin{array}{l}\text { Areas under significant } \\
\text { threat from uncontrolled } \\
\text { wildfires; areas co-managed } \\
\text { by communities and } \\
\text { conservation agencies }\end{array}$ \\
\hline $\begin{array}{l}\text { Late dry } \\
\text { season burns }\end{array}$ & $x$ & $\checkmark$ & $\checkmark$ & $?$ & $<>$ & $\checkmark$ & $x$ & $x$ & $x$ & $<>$ & $\begin{array}{l}\text { Areas with high levels of } \\
\text { woody shrub encroachment }\end{array}$ \\
\hline $\begin{array}{l}\text { Early wet } \\
\text { season burns }\end{array}$ & $\checkmark$ & $\checkmark$ & $<>$ & ? & $?$ & $\checkmark$ & $\checkmark$ & $<>$ & ? & $\checkmark$ & $\begin{array}{l}\text { Most savanna protected } \\
\text { areas }\end{array}$ \\
\hline $\begin{array}{l}\text { Patch mosaic } \\
\text { burning }\end{array}$ & ? & ? & ? & $\checkmark$ & $x$ & $\checkmark$ & ? & ? & ? & $x$ & $\begin{array}{l}\text { Small- to medium-sized } \\
\text { protected areas }(<100000 \text { ha) }\end{array}$ \\
\hline Laissez faire & ? & $<>$ & $x$ & ? & $x$ & $x$ & $x$ & $x$ & ? & ? & $\begin{array}{l}\text { Protected areas with few } \\
\text { resources for fire } \\
\text { management, where current } \\
\text { fire patterns are not } \\
\text { detrimental; areas that } \\
\text { seldom burn (e.g. riparian } \\
\text { zones) }\end{array}$ \\
\hline
\end{tabular}


noted that this policy is not appropriate for areas smaller than 20000 ha, but many gaps remain in our understanding of this approach. For example, although pyrodiversity is argued to beget biodiversity (Martin \& Sapsis 1992), it remains unclear exactly what degree of pyrodiversity would be needed to conserve biodiversity (Parr \& Andersen 2006). Finally, hands-off (laissez faire) approaches to fire management are not ideal, but may be adopted if there is no evidence that the prevailing fire regime has detrimental consequences. A laissez faire approach may also be necessitated in protected areas that lack fire management resources, or in instances where fire management funds have been redirected to address other issues of conservation policy. For example, the imperative to curb rampant poaching of rhinoceros in South Africa's protected areas has placed undue pressure on managers (Ferreira, Pfab \& Knight 2014), resulting in funds being redirected to anti-rhinoceros poaching activities and reducing the capacity for inter alia fire management. Similarly, fire management has become much less of a priority in Hwange National Park since the onset of the ongoing economic recession in Zimbabwe (Pricope \& Binford 2012).

\section{Fire management trade-offs and conflicts}

Managers of protected areas normally use fire to influence a conservation-orientated outcome, and in many instances, a particular type of fire may be used to achieve the desired goal, but it could at the same time also precipitate unintended additional outcomes. Furthermore, a single protected area may have multiple desired goals for fire management that could contradict each other. Managers may, therefore, have to consciously consider making trade-offs when selecting a particular approach for fire management. For example, highintensity fires are normally used to reduce the cover of woody plants, which is expected to accelerate because of increasing $\mathrm{CO}_{2}$ levels in the 21st century (Bond \& Midgley 2012). However, the effectiveness of high-intensity fires may have to be reduced to accommodate safety needs. In addition, Smit et al. (2016) noted that the use of repeated high-intensity fires simultaneously causes both a positive (reduction in cover of short shrubs) and a negative (loss of tall trees) outcome, and that managers would need to consider trade-offs. Case and Staver (2017) also noted that grazing mammals and fire are competitors for grass fuel, and because high-intensity fires require high fuel loads, managers would face a stark choice between the maintenance of short-term grazer populations (which would reduce fuel loads) and prevention of woody encroachment (which requires a build-up of high fuel loads).

Another example includes the trade-offs necessitated by modern threats to ecosystem health. Many approaches to fire management were designed to promote conservation goals in pristine ecosystems unaffected by the need to reduce greenhouse gas emissions, to sequester carbon (which would require the encouragement of woody encroachment, Lipsett-Moore et al. 2018), to combat invasive alien species (Sala et al. 2000) or to accommodate traditional burning practices, which may be at odds with conservation objectives
(Ryan \& Williams 2011; Shaffer et al. 2010). These pressures are increasingly brought to bear on fire managers, and fire management policies will, therefore, have to be developed taking potential conflicting goals into account, and tradeoffs may be needed to accommodate an optimal range of outcomes.

\section{Imposing desired fire regimes}

Once a particular approach to fire management is chosen to promote desired outcomes, managers should attempt to maintain elements of the fire regime within certain limits by manipulating the season, frequency, intensity and size of fires. However, implementing and maintaining any chosen fire regime in the long term remain notoriously challenging, particularly in large conservation areas (Smit et al. 2016). Managers often have to contend with unplanned fires, which alter predefined burn-area targets or seasonal distributions (Eriksen 2007; Van Wilgen et al. 2004). For example, a substantial number of fires were reported in the Hluhluwe-iMfolozi Park during the time when fires were actively suppressed (1930-1940) (Berry \& Macdonald 1979), and most areas in the Kruger National Park that had been burnt during the first 9 years of the lightning fire policy were ignited by sources other than lightning (Van Wilgen et al. 2007). Furthermore, a study in the 2 million hectare Kruger National Park (Van Wilgen et al. 2004) found that four major changes to the fire management policy over six decades had little effect on the total area burnt, which was strongly related to rainfall (and, therefore, grass fuel loads) in the preceding 2 years. Management did, however, alter the spatial heterogeneity of fires and their seasonal distribution over this period. Similarly, in the smaller (20000 ha) Pilanesberg National Park, Brockett et al. (2001) observed that the spatial heterogeneity of fire patterns increased a few years after the introduction of the patchmosaic burning policy. It appears, therefore, that managers should be able to influence the fire regime in terms of season and size distributions (and possibly in intensity, Smit et al. 2016), but not in terms of fire frequency. Despite the difficulty of maintaining desired fire return periods, it remains an important consideration for managers, irrespective of the chosen fire regime, as both too frequent and too infrequent fires can result in undesired consequences (McCleery et al., 2018). Typically, areas of higher rainfall can be burnt more frequently, whilst areas of lower rainfall (<650 mm MAP) should only be burnt in years of above-average rainfall and when the botanical composition suggests that a fire would be beneficial (Trollope et al. 2014).

\section{Acknowledgements}

The authors would like to thank Marie Theron and Nicola van Wilgen for assistance in sourcing the publications cited in this review, and Jeremy Russel-Smith for comments on an earlier draft. W.A.N. acknowledges logistical support received from African Parks Ltd. 


\section{Competing interests}

The authors have declared that no competing interests exist.

\section{Authors' contributions}

All authors conceptualised the study. W.A.N. and B.W.v.W. jointly sourced and interpreted the relevant literature and cowrote the research article. All authors approved the final text.

\section{Funding information}

This study was funded by the Earthwatch Institute (grant to A.J.L.) under the Majete Wildlife Research Programme, Malawi, the DSI-NRF Centre for Invasion Biology, Stellenbosch University, and the National Research Foundation of South Africa (Grant 109467 to B.W.v.W.). None of the funding agencies played any role in the design of the study, collection, analysis, interpretation of data or in writing the article.

\section{Data availability statement}

Data sharing is not applicable to this research article as no new data were created or analysed in this study.

\section{Disclaimer}

The views and opinions expressed in this article are those of the authors and do not necessarily reflect the official policy or position of any affiliated agency of the authors.

\section{References}

Archibald, S., Beckett, H., Bond, W.J., Coetsee, C., Druce, D.J. \& Staver, C.A., 2017 'Interactions between fire and ecosystem processes', in Conserving Africa's megadiversity in the anthropocene: The Hluhluwe-iMfolozi Park story, pp. 233-262, Cambridge University Press, Cambridge.

Archibald, S., Lehmann, C.E.R., Gómez-Dans, J.L. \& Bradstock, R.A., 2013, 'Defining pyromes and global syndromes of fire regimes', Proceedings of the National Academy of Sciences of the United States of America 110(16), 6442-6447. https:// doi.org/10.1073/pnas.1211466110

Aubréville, A.M.A., 1947, 'The disappearance of the tropical forests of Africa', Unasylva 1(1), 5-11. Reprinted in Fire Ecology 9(2), 3-13, (2013). https://doi. org/10.1007/BF03400624

Austen, B., 1972, 'The history of veld burning in the Wankie National Park Rhodesia', in Proceedings of the annual tall timbers fire ecology conference, 11 Tall Timbers Research Station, June 8-9, 1972, Tallahassee, FL, pp. 277-296.

Balfour, D.A. \& Howison, O.E., 2001, 'Spatial and temporal variation in a mesic savanna fire regime: Responses to variation in annual rainfall', African Journal of Range \& Forage Science 19(1), 45-53. https://doi.org/10.2989/10220110209485773

Beale, C.M., Courtney Mustaphi, C.J., Morrison, T.A., Archibald, S., Anderson, T.M., Dobson, A.P. et al., 2018, 'Pyrodiversity interacts with rainfall to increase bird and mammal richness in African savannas', Ecology Letters 21(4), 557-567. https:// doi.org/10.1111/ele.12921

Berry, A. \& Macdonald, I.A.W., 1979, Fire regime characteristics in the HluhluweCorridor-Umfolozi Game Reserve Complex in Zululand. Area description and an analysis of causal factors and seasonal incidence of fire in the central complex with particular reference to the period 1955 to 1978, Unpublished report, Nata Parks Board, Pietermaritzburg.

Biggs, H.C. \& Potgieter, A.L.F., 1999, 'Overview of the fire management policy of the Kruger National Park', Koedoe 42(1), 101-110. https://doi.org/10.4102/koedoe. v42i1.227

Biggs, H.C. \& Rogers, K.H., 2003, 'An adaptive system to link science, monitoring and management in practice', in J.T. Du Toit, K.H. Rogers \& H.C. Biggs (eds.), The Kruge experience: Ecology and management of savanna heterogeneity, pp. 59-80, Island Press, Washington, DC.

Bond, W.J., 2019, Open ecosystems: Ecology and evolution beyond the forest edge, Oxford University Press, Oxford. https://doi.org/10.1093/oso/9780198812456.001.0001

Bond, W.J. \& Archibald, S., 2003, 'Confronting complexity: Fire policy choices in South African savanna parks', International Journal of Wildland Fire 12(4), 381-389. https://doi.org/10.1071/WF03024
Bond, W.J. \& Midgley, G.F., 2012, 'Carbon dioxide and the uneasy interactions of trees and savannah grasses', Philosophical Transactions of the Royal Society of London B: Biological Sciences 367(1588), 601-612 https://doi.org/10.1098/ rstb.2011.0182

Brockett, B.H., Biggs, H.C. \& Van Wilgen, B.W., 2001, 'A patch mosaic burning system for conservation areas in southern African savannas', International Journal of Wildland Fire 10(2), 169-183. https://doi.org/10.1071/WF01024

Browne, C. \& Bond, W., 2011, 'Firestorms in savanna and forest ecosytems: Curse or cure?', Veld \& Flora 97(2), 62-63.

Brynard, A.M., 1958, Memorandum in verband met die beleid van driejaarlikse rotasiebrand in die Nationale Krugerwildtuin, Addendum K 1, Board of Curators of National Parks, Pretoria.

Brynard, A.M., 1972, 'Controlled burning in the Kruger National Park-history and development of a veld burning policy', Tall Timbers Fire Ecology Conference Proceedings 838, viewed 22 April 2020, from http://agris.fao.org/agris-search/ search.do?recordID=US201302337593.

Bukombe, J., Smith, S.W., Kija, H., Loishooki, A., Sumay, G., Mwita, M. et al., 2018, 'Fire regulates the abundance of alien plant species around roads and settlements in the Serengeti National Park', Management of Biological Invasions 9(3), 357-367. https://doi.org/10.3391/mbi.2018.9.3.17

Case, M.F. \& Staver, A.C., 2017, 'Fire prevents woody encroachment only at higherthan-historical frequencies in a South African savanna', Journal of Applied Ecology 64(3), 955-962. https://doi.org/10.1111/1365-2664.12805

Charter, J.R. \& Keay, R.W., 1960, 'Assessment of the Olokemeji fire-control experiment (investigation 254) 28 years after institution', Nigerian Forestry Information Bulletin 3, 1-32.

Chipp, T.F., 1922, Forest officers' handbook of the Gold Coast, Ashanti and the Northern Territories, Gold Coast Colony Government Printer, Accra.

Clements, F.E., 1916, Plant succession: An analysis of the development of vegetation Carnegie Institution of Washington, Washington, D.C.

Crowley, G., Garnett, S. \& Shephard, S., 2009, 'Impact of storm-burning on Melaleuca viridiflora invasion of grasslands and grassy woodlands on Cape York Peninsula, Australia', Austral Ecology 34(2), 196-209. https://doi.org/10.1111/j.14429993.2008.01921.x

Dew, L.A., Rozen-Rechels, D., Le Roux, E., Cromsigt, J.P.G.M. \& Te Beest, M., 2017 'Evaluating the efficacy of invasive plant control in response to ecological factors', South African Journal of Botany 109, 203-213. https://doi.org/10.1016/j. sajb.2016.12.007

Docherty, T.D.S., Hethcoat, M.G., MacTavish, L.M., MacTavish, D., Dell, S., Stephens, P.A et al., 2020, 'Burning savanna for avian species richness and functional diversity', Ecological Applications 30(4), e02091. https://doi.org/10.1002/eap.2091

Du Plessis, W.P., 1997, 'Refinements to the burning strategy in the Etosha National Park, Namibia', Koedoe 40(1), 63-76. https://doi.org/10.4102/koedoe.v40i1.264

Eby, S.L., Dempewolf, J., Holdo, R.M. \& Metzger, K.L., 2015, 'Fire in the Serengeti ecosystem: History, drivers, and consequences', in A.R.E. Sinclair, K.L. Metzger, S.A.R. Mduma \& J.M. Fryxell (eds.), Serengeti IV: Sustaining biodiversity in a coupled human-natural system, pp. 73-104, The University of Chicago Press, Chicago, U.S.

Eckhardt, H.C., Van Wilgen, B.W. \& Biggs, H.C., 2000, 'Trends in woody vegetation cover in the Kruger National Park, South Africa, between 1940 and 1998', African Journa of Ecology 38(2), 108-115. https://doi.org/10.1046/j.1365-2028.2000.00217.x

Edwards, D., 1984, 'Fire regimes in the biomes of South Africa', in P. De V. Booysen \& N.M. Tainton (eds.), Ecological effects of fire in South African ecosystems, pp. 19-37, Springer, Heidelberg, Berlin.

Egunjobi, J.K., 2018, 'An appraisel of the savanna burning problem', in S.S. Ajayi \& L.B. Halstead (eds.), Wildlife management in savannah woodland, pp. 161-164, Routledge Revivals, Taylor and Francis Ltd., London.

Eriksen, C., 2007, 'Why do they burn the "bush"? Fire, rural livelihoods, and conservation in Zambia', Geographical Journal 173(3), 242-256. https://doi. org/10.1111/j.1475-4959.2007.00239.x

Ferreira, S.M., Pfab, M. \& Knight, M.H., 2014, 'Management strategies to curb rhino poaching: An exploration of alternative options', South African Journal of Science 110(5), 6. https://doi.org/10.1590/sajs.2014/20120055

Foxcroft, L.C., Pyšek, P., Richardson, D.M. \& Genovesi, P., 2013, Plant invasions in protected areas: Patterns, problems and challenges, vol. 7, Springer Science \& Business Media, Berlin. https://doi.org/10.1007/978-94-007-7750-7

Fyumagwa, R.D., Runyoro, V., Horak, I.G. \& Hoare, R., 2007, 'Ecology and control of ticks as disease vectors in wildlife of the Ngorongoro Crater, Tanzania', African Journal of Wildlife Research 37(1), 79-90. https://doi.org/10.3957/0379-436937.1.79

Geldenhuys, C.J., 1977, 'The effect of different regimes of annual burning on two woodland communities in Kavango', South African Forestry Journal 103(1), 32-42. https://doi.org/10.1080/00382167.1977.9629467

Goldammer, J.G. \& De Ronde, C. (eds.), 2004, Wildland fire management handbook for sub-Sahara Africa, African Minds, Global Fire Monitoring Center (GFMC), Freiburg.

Goodenough, A.E., Harrell, A.N., Keating, R.L., Rolfe, R.N., Stubbs, H., MacTavish, L et al., 2017, 'Managing grassland for wildlife: The effects of rotational burning on tick presence and abundance in African savan
2017(4), 1-9. https://doi.org/10.2981/wlb.00318

Govender, N., Mutanga, O. \& Ntsala, D., 2012, 'Veld fire reporting and mapping techniques in the Kruger National Park, South Africa, from 1941 to $2011^{\prime}$, African
Journal of Range and Forage Science 29(2), 63-73. https://doi.org/10.2989/102 Journal of Range and 
Govender, N., Trollope, W.S.W. \& Van Wilgen, B.W., 2006, 'The effect of fire season, fire frequency, rainfall and management on fire intensity in savanna vegetation in South Africa', Journal of Applied Ecology 43(4), 748-758. https://doi.org/10.1111/ j.1365-2664.2006.01184.x

Green Climate Fund (GCF), 2017, Terms of reference for the pilot programme for $R E D D+$ results-based payments, Green Climate Fund Incheon.

Gureja, N. \& Owen-Smith, N., 2002, 'Comparative use of burnt grassland by rare antelope species in a lowveld game ranch, South Africa', South African Journal of Wildlife Research 32(1), 31-38.

Holdo, R.M., 2005, 'Stem mortality following fire in Kalahari sand vegetation: Effects of frost, prior damage, and tree neighbourhoods', Plant Ecology 180(1), 77-86. https://doi.org/10.1007/s11258-005-2796-4

Hough, J.L., 1993, 'Why burn the bush? Social approaches to bush-fire management in West African national parks', Biological Conservation 65(1), 23-28. https://doi. org/10.1016/0006-3207(93)90192-4

Hudak, A.T., 1999, 'Rangeland mismanagement in South Africa: Failure to apply ecological knowledge', Human Ecology 27, 55-78. https://doi. org/10.1023/A:1018705300730

Hudak, A.T., Brockett, B.H. \& Wessman, C.A., 1998, 'Fire scar mapping in a southern African savanna', International Geoscience and Remote Sensing Symposium (IGARSS) 3, 1608-1610. https://doi.org/10.1109/igarss.1998.691638

Hudak, A.T., Fairbanks, D.H.K. \& Brockett, B.H., 2004, 'Trends in fire patterns in southern African savanna under alternative land use practices', Agriculture, Ecosystems and Environment 101(2-3), 307-325. https://doi.org/10.1016/j. agee.2003.09.010

Joubert, S., 2007, The Kruger National Park: A history, vol. 2, High Branching, Johannesburg.

Kamau, P.N. \& Medley, K.E., 2014, 'Anthropogenic fires and local livelihoods at Chyulu Hills, Kenya', Landscape and Urban Planning 124, 76-84. https://doi. org/10.1016/j.landurbplan.2014.01.010

Kamminga, E., 2001, Impact of the integrated forest fire management program on rural livelihoods in East Caprivi region, Namibia, pp. 1-43 Namibia Finland Forestry Program, Directorate of Forestry, Ministry of Environment and Tourism, Windhoek, Namibia.

Komarek, E., 1972, 'Fire in Africa', in Proceeding of the annual tall timbers fire ecology conference, 11, Tall Timbers Research Station, June 8-9, 1972, Tallahassee, FL.

Kull, C.A., 2002, 'Madagascar a flame: Landscape burning as peasant protest, resistance, or a resource management tool?', Political Geography 21(7), 927-953. https://doi.org/10.1016/S0962-6298(02)00054-9

Landry, J.S. \& Matthews, H.D., 2016, 'Non-deforestation fire vs. fossil fue combustion: The source of $\mathrm{CO}_{2}$ emissions affects the global carbon cycle and climate responses', Biogeosciences 13(7), 2137-2149. https://doi.org/10.5194/ bg-13-2137-2016

Laris, P., 2002, 'Burning the seasonal mosaic: Preventative burning strategies in the wooded savanna of southern Mali', Human Ecology 30(2), 155-186. https://doi. org/10.1023/A:1015685529180

Laris, P. \& Wardell, D.A., 2006, 'Good, bad or 'necessary evil'? Reinterpreting the colonial burning experiments in the savanna landscapes of West Africa', The Geographic Journal 172(4), 271-290. https://doi.org/10.1111/j.1475-4959.2006. 00215.x

Lipsett-Moore, G.J., Wolff, N.H. \& Game, E.T., 2018, 'Emissions mitigation opportunities for savanna countries from early dry season fire management', Nature Communications 9(1), 1-8. https://doi.org/10.1038/s41467-018-04687-7

Martin, R.E. \& Sapsis, D.B., 1992, 'Fires as agents of biodiversity: Pyrodiversity promotes biodiversity', in Proceedings of the conference on biodiversity of Northwest California ecosystems, Cooperative extension, University of California, Berkeley, CA, October 28-30, 1991, pp. 150-157.

Masocha, M., Skidmore, A.K., Poshiwa, X. \& Prins, H.H.T., 2011, 'Frequent burning promotes invasions of alien plants into a mesic African savanna', Biological Invasions 13(7), 1641-1648. https://doi.org/10.1007/s10530-010-9921-6

McCleery, R., Monadjem, A., Baiser, B., Fletcher, R., Vickers, K., Kruger, L., 2018 'Animal diversity declines with broad-scale homogenization of canopy cover in African savannas', Biological Conservation 226, 54-62.

McGranahan, D.A. \& Kirkman, K.P., 2013, 'Multifunctional rangeland in Southern Africa: Managing for production, conservation, and resilience with fire and grazing', Land 2(2), 176-193. https://doi.org/10.3390/land2020176

Mentis, M.T. \& Bailey, A.W., 1990, 'Changing perceptions of fire management in savanna parks', Journal of the Grassland Society of Southern Africa 7(2), 81-85. https://doi.org/10.1080/02566702.1990.9648211

Messina, M., Cunliffe, R., Farcomeni, A., Malatesta, L., Smit, I.P.J., Testolin, R. et al. 2018, 'An innovative approach to disentangling the effect of management and environment on tree cover and density of protected areas in African savanna',
Forest Ecology and Management 419-420, 1-9. https://doi.org/10.1016/j. Forest Ecology and
foreco.2018.03.019

Meyer, C.P., Cook, G.D., Reisen, F., Smith, T.E.L., Tattaris, M., Russell-Smith, J. et al., 2012, 'Direct measurements of the seasonality of emission factors from savann fires in northern Australia', Journal of Geophysical Research: Atmospheres 117(D20), 1-14. https://doi.org/10.1029/2012JD017671

Moura, L.C., Scariot, A.O., Schmidt, I.B., Beatty, R. \& Russell-Smith, J., 2019, 'The legacy of colonial fire management policies on traditional livelihoods and ecological sustainability in savannas: Impacts, consequences, new directions', Journal of Environmental Management 232, 600-606. https://doi.org/10.1016/j. jenvman.2018.11.057
Mulqueeny, C.M., Goodman, P.S. \& O'Connor, T.G., 2010, 'Landscape-level differences in fire regime between block and patch-mosaic burning strategies in Mkuzi Game Reserve, South Africa', African Journal of Range \& Forage Science 27(3), 143-150. Reserve, South Africa, African Journal of Range \& Fo
https://doi.org/10.2989/10220119.2010.527300

Mulqueeny, C.M., Goodman, P.S. \& O'Connor, T.G., 2011, 'Determinants of interannual variation in the area burnt in a semiarid African savanna', International Journal of Wildland Fire 20(4), 532-539. https://doi.org/10.1071/WF08141

Munyati, C., Shaker, P. \& Phasha, M.G., 2011, 'Using remotely sensed imagery to monitor savanna rangeland deterioration through woody plant proliferation: A case study from communal and biodiversity conservation rangeland sites in Mokopane, South Africa', Environmental Monitoring and Assessment 176(1-4) 293-311. https://doi.org/10.1007/s10661-010-1583-4

Nangendo, G., Stein, A., Ter Steege, H. \& Bongers, F., 2005, 'Changes in woody plant composition of three vegetation types exposed to a similar fire regime for over 46 years', Forest Ecology and Management 217(2-3), 351-364. https://doi. 46 years', Forest Ecology and 1 ar
org/10.1016/j.foreco.2005.07.007

Nangendo, G., Ter Steege, H. \& Bongers, F., 2006, 'Composition of woody species in a dynamic forest-woodland-savannah mosaic in Uganda: Implications for conservation and management', Biodiversity and Conservation 15(4), 1467-1495. https://doi.org/10.1007/s10531-005-1876-z

Nieman, W.A., 2020, Integrated fire management plan: Majete Wildlife Reserve, Malawi, Technical report, African Parks Ltd, Johannesburg.

Norton-Griffiths, M., 1979, 'The influence of grazing, browsing, and fire on the vegetation dynamics of the Serengeti', in A.R.E. Sinclair \& $M$. Norton-Griffith (eds.), Serengeti: Dynamics of an ecosystem, pp. 310-352, University of Chicago Press, Chicago, IL.

O'Connor, T.G., Puttick, J.R. \& Hoffman, M.T., 2014, 'Bush encroachment in southern Africa: Changes and causes', African Journal of Range \& Forage Science 31(2), 67-88. https://doi.org/10.2989/10220119.2014.939996

Owen, J.S., 1972, 'Fire management in the Tanzania National Parks', in Tall timbers fire ecology conference proceedings, 11, Tall Timbers Research Station, June 8-9, 1972, Tallahassee, $\mathrm{FL}$

Parr, C.L. \& Andersen, A.N., 2006, 'Patch mosaic burning for biodiversity conservation: A critique of the pyrodiversity paradigm', Conservation Biology 20(6), 1610-1619. https://doi.org/10.1111/j.1523-1739.2006.00492.x

Parr, C.L. \& Brockett, B.H., 1999, 'Patch-mosaic burning: A new paradigm for savanna fire management in protected areas?', Koedoe 42(2), 117-130. https://doi. org/10.4102/koedoe.v42i2.237

Parr, C.L., Woinarski, J.C.Z. \& Pienaar, D.J., 2009, 'Cornerstones of biodiversity conservation? Comparing the management effectiveness of Kruger and Kakadu National Parks, two key savanna reserves', Biodiversity and Conservation 18(13) 3643-3662. https://doi.org/10.1007/s10531-009-9669-4

Pfab, M.F. \& Witkowski, E.T.F., 2000, 'A simple population viability analysis of the critically endangered Euphorbia clivicola under four management scenarios', Biological Conservation 96(3), 263-270. https://doi.org/10.1016/S00063207(00)00088-4

Phillips, J.F.V., 1930, 'Fire: Its influence on biotic communities and physical factors in South and East Africa', African Journal of Science 27, 352-367.

Pricope, N.G. \& Binford, M.W., 2012, 'A spatio-temporal analysis of fire recurrence and extent for semi-arid savanna ecosystems in southern Africa using moderateresolution satellite imagery', Journal of Environmental Management 100, 72-85. https://doi.org/10.1016/j.jenvman.2012.01.024

Rains, A.B., 1963, Grassland research in northern Nigeria 1952/62, Samaru misc, Paper No. 1, Institute for Agricultural Research, Ahmadu Bello University, Zaria.

Ribeiro, N.S., Cangela, A., Chauque, A., Bandeira, R.R. \& Ribeiro-Barros, A.I., 2017, 'Characterisation of spatial and temporal distribution of the fire regime in Niassa National Reserve, northern Mozambique', International Journal of Wildland Fire 26(12), 1021-1029. https://doi.org/10.1071/WF17085

Ross, I.C., Field, C.R. \& Harrington, G.N., 1976, 'The savanna ecology of Kidepo Valley National Park, Uganda: III, Animal populations and park management recommendations', African Journal of Ecology 14(1), 35-48. https://doi. org/10.1111/j.1365-2028.1976.tb00150.x

Roux, E., 1969, Grass, a story of Frankenwald, Oxford University Press, Cape Town.

Russell-Smith, J., Monagle, C., Jacobsohn, M., Beatty, R.L., Bilbao, B., Millán, A. et al., 2013, 'Can savanna burning projects deliver measurable greenhouse emissions reductions and sustainable livelihood opportunities in fire-prone settings?', Climatic Change 140(1), 47-61. https://doi.org/10.1007/s10584-013-0910-5

Ryan, C.M. \& Williams, M., 2011, 'How does fire intensity and frequency affect miombo woodland tree populations and biomass?', Ecological Applications 21(1), 48-60. https://doi.org/10.1890/09-1489.1

Sala, O.E., lii, F.S.C., Armesto, J.J., Berlow, E., Bloomfield, J., Dirzo, R. et al., 2000 'Global biodiversity scenarios for the year 2100', Science 287, 1770-1774. https:// doi.org/10.1126/science.287.5459.1770

Sannier, C.A.D., Taylor, J.C. \& Du Plessis, W., 2002, 'Real-time monitoring of vegetation biomass with NOAA-AVHRR in Etosha National Park, Namibia, for fire risk assessment', International Journal of Remote Sensing 23(1), 71-89. https://doi. org/10.1080/01431160010006863

Saxon, E.C., 1984, Anticipating the inevitable: A patch-burn strategy for fire management at Uluru (Ayers Rock-Mount Olga) National Park (NT), Commonwealth Scientific and Industrial Research Organization, Melbourne, Australia.

Scholes, R.J. \& Archer, S.R., 1997, 'Tree-grass interactions in savannas', Annual Review of Ecology and Systematics 28, 517-544. https://doi.org/10.1146/annurev. ecolsys.28.1.517 
Scholes, R.J. \& Walker, B.H., 1993, An African savanna: Synthesis of the Nylsvley study, Cambridge University Press, Cambridge.

Scott, J.D., 1955, 'Principles of pasture management', in D. Meridith (ed.), The grasses and pastures of South Africa, pp. 601-623, Central News Agency Ltd., Johannesbur.

Shaffer, L.J., Hall, B. \& Street, J., 2010, 'Indigenous fire use to manage savanna landscapes in southern mozambique', Fire Ecology 6(2), 43-59. https://doi. org/10.4996/fireecolgy.0602043

Siegfried, W.R., 1981, 'The incidence of veld-fire in the Etosha National Park, 19701979', Madoqua 12(4), 225-230.

Smit, I.P.J. \& Archibald, S., 2019, 'Herbivore culling influences spatio-temporal patterns of fire in a semiarid savanna', Journal of Applied Ecology 56(3), 711-721. https://doi.org/10.1111/1365-2664.13312

Smit, I.P.J., Asner, G.P., Govender, N., Vaughn, N.R. \& Van Wilgen, B.W., 2016, 'An examination of the potential efficacy of high-intensity fires for reversing woody encroachment in savannas', Journal of Applied Ecology 53(5), 1623-1633. https:// doi.org/10.1111/1365-2664.12738

Smit, I.P.J., Smit, C.F., Govender, N., Van der Linde, M. \& Macfadyen, S., 2013, 'Rainfall, geology and landscape position generate large-scale spatiotemporal fire pattern heterogeneity in an African savanna', Ecography 36(4), 447-459. https://doi. heterogeneity in an African savanna',
org/10.1111/j.1600-0587.2012.07555.x

Stander, P.E., Nott, T.B. \& Mentis, M.T., 1993, 'Proposed burning strategy for a semiarid African savanna', African Journal of Ecology 31(4), 282-289. https://doi. org/10.1111/j.1365-2028.1993.tb00542.x

Stebbing, E.P., 1937, The forests of west Africa and the Sahara: A study of modern conditions, W \& R Chambers, London.

Stronach, N.R.H., 1988, The management of fire in Serengeti National Park, objectives and prescriptions, Unpublished manuscript, Tanzania National Parks, Arusha.

Stronach, N.R.H. \& McNaughton, S.J., 1989, 'Grassland fire dynamics in the Serengeti ecosystem, and a potential method of retrospectively estimating fire energy' Journal of Applied Ecology 26(3), 1025-1033. https://doi.org/10.2307/2403709

Te Beest, M., Cromsigt, J.P.G.M., Ngobese, J. \& Olff, H., 2012, 'Managing invasions at the cost of native habitat? An experimental test of the impact of fire on the invasion of Chromolaena odorata in a South African savanna', Biological Invasion 14, 607-618. https://doi.org/10.1007/s10530-011-0102-z

Te Beest, M., Howison, O.E., Howison, R.A., Dew, L.A., Poswa, M.M., Dumalisle, L. et al., 2017, 'Successful control of the invasive shrub Chromolaena odorata in Hluhluwe-iMfolozi Park', in J.P.G.M. Cromsight, S. Archibald \& N. Owen-Smith (eds.), Conserving Africa's mega-diversity in the anthropocene: The Hluhluwe(eds.), Conserving Africa's mega-diversity in the anthropocene: The
iMfolozi Park story, p. 358, Cambridge University Press, Cambridge.

Te Beest, M., Mpandza, N.J. \& Olff, H., 2015, 'Fire and simulated herbivory have antagonistic effects on resistance of savanna grasslands to alien shrub invasion' Journal of Vegetation Science 26(1), 114-122. https://doi.org/10.1111/ journal of

Tokura, W., Jack, S.L., Anderson, T. \& Hoffman, M.T., 2018, 'Long-term variability in vegetation productivity in relation to rainfall, herbivory and fire in Tswalu Kalahari Reserve', Koedoe 60(1), 1-18. https://doi.org/10.4102/koedoe.v60i1.1473

Trapnell, C.G., 1959, 'Ecological results of woodland burning in Northern Rhodesia', The Journal of Ecology 47(1), 129-168. https://doi.org/10.2307/2257252

Trollope, L.A. \& Trollope, L.A., 2010, 'Fire effects and management in African grasslands and savannas', Range and Animal Sciences and Resources Management 2, 121-145.

Trollope, W., Van Wilgen, B., Trollope, L.A., Govender, N. \& Potgieter, A.L., 2014, 'The long-term effect of fire and grazing by wildlife on range condition in moist and arid savannas in the Kruger National Park', African Journal of Range \& Forage Science 31(3), 199-208. https://doi.org/10.2989/10220119.2014.884511

Trollope, W.S.W., 2007, 'Fire - A key factor in the ecology and management of African grasslands and savannas', in Proceedings of the 23rd tall timbers fire ecology conference: Fire in Grassland and Shrubland Ecosystems, Tall Timbers Research Station, Tallahassee, Florida, pp. 2-14.

Trollope, W.S.W., Biggs, H.C., Potgieter, A.L.F. \& Zambatis, N., 1995, 'A structured vs a wilderness approach to burning in the Kruger National Park in South Africa', in N.E. West (ed.), Rangelands in a sustainable biosphere, pp. 574-575, Society fo Range Management, Denver.

Trollope, W.S.W., Fyumagwa, R. \& Trollope, L.A., 2003, 'Relation between range condition and the incidence of ticks in the Ngorongoro Crater, Tanzania', in Proceedings of the VII international rangeland conference, Grassland Society of Southern Africa, 26 July-1 August 2003, Durban, South Africa, pp. 531-533.
Trollope, W.S.W., Trollope, L.A., De Bruno Austin, C., Held, A.C., Emery, A. \& Hines, C.J. ${ }^{2}$ 2006, A fire management plan for the Okavango Delta Ramsar site in Botswana, Botswana Department of Forestry and Range Resources, Gabarone.

Van Der Werf, G.R., Randerson, J.T., Giglio, L., Collatz, G.J., Mu, M., Kasibhatla, P.S. et al., 2010, 'Global fire emissions and the contribution of deforestation, savanna, forest, agricultural, and peat fires (1997-2009)', Atmospheric Chemistry and Physics 10(23), 11707-11735. https://doi.org/10.5194/acp-10-11707-2010

Van Der Werf, G.R., Randerson, J.T., Giglio, L., Van Leeuwen, T.T., Chen, Y., Rogers, B.M. et al., 2017, 'Global fire emissions estimates during 1997-2016', Earth System Science Data 9(2), 697-720. https://doi.org/10.5194/essd-9-697-2017

Van Wilgen, B.W., 2009, 'The evolution of fire management practices in savanna protected areas in South Africa', South African Journal of Science 5(9-10), 343349. https://doi.org/10.4102/sajs.v105i9/10.107

Van Wilgen, B.W. \& Biggs, H.C., 2011, 'A critical assessment of adaptive ecosystem management in a large savanna protected area in South Africa', Biological Conservation 144(4), 1179-1187. https://doi.org/10.1016/j.biocon.2010.05.006

Van Wilgen, B.W., Biggs, H.C. \& Potgieter, A.L.F., 1998, 'Fire management and research in the Kruger National Park, with suggestions on the detection of thresholds of potential concern', Koedoe 41(1), 69-87. https://doi.org/10.4102/koedoe.v41i1.248

Van Wilgen, B.W, Fill, J.M., Govender, N. \& Foxcroft, L.C., 2017, 'An assessment of the evolution, costs and effectiveness of alien plant control operations in Kruger
National Park, South Africa', NeoBiota 35, 35-59. https://doi.org/10.3897/ neobiota.35.12391

Van Wilgen, B.W., Govender, N. \& Biggs, H.C., 2007, 'The contribution of fire research to fire management: A critical review of a long-term experiment in the Kruger National Park, South Africa', International Journal of Wildland Fire 16(2), 519-530. https://doi.org/10.1071/WF06115

Van Wilgen, B.W., Govender, N., Ntsala, D. \& Funda, X.N., 2004, 'Response of savanna fire regimes to changing fire-management policies in a large African National Park', Conservation Biology 18(6), 1533-1540. https://doi.org/10.1111/j.15231739.2004.00362.x

Van Wilgen, B.W., Govender, N., Smit, I.P.J. \& Macfadyen, S., 2014, 'The ongoing development of a pragmatic and adaptive fire management policy in a large African savanna protected area', Journal of Environmental Management 132, 358-368. https://doi.org/10.1016/j.jenvman.2013.11.003

Van Wilgen, B.W., Govender, N. \& MacFadyen, S., 2008, 'An assessment of the implementation and outcomes of recent changes to fire management in the Kruge National Park', Koedoe 50(1), 22-31. https://doi.org/10.4102/koedoe.v50i1.135

Van Wilgen, B.W., Trollope, W.S.W., Biggs, H.C., Potgieter, A.L.F. \& Brockett, B.H., 2003, 'Fire as a driver of ecosystem variability', in J.T. du Toit, K.H. Rogers \& H.C. Biggs (eds.), The Kruger experience: Ecology and management of savanna heterogeneity, pp. 149-170, Island Press, Washington, DC.

Verbesselt, J., Somers, B., Lhermitte, S., Jonckheere, I., Van Aardt, J. \& Coppin, P. 2007, 'Monitoring herbaceous fuel moisture content with SPOT VEGETATION time-series for fire risk prediction in savanna ecosystems', Remote Sen
Environment 108(4), 357-368. https://doi.org/10.1016/j.rse.2006.11.019

Verbesselt, J., Somers, B., Van Aardt, J., Jonckheere, I. \& Coppin, P., 2006, 'Monitoring herbaceous biomass and water content with SPOT VEGETATION time-series
to improve fire risk assessment in savanna ecosystems', Remote Sensing of to improve fire risk assessment in savanna ecosystems', Remote Sen
Environment 101(3), 399-414. https://doi.org/10.1016/j.rse.2006.01.005

Vincent, J., 1970, 'The history of Umfolozi Game Reserve, Zululand, as it relates to management', Lammergeyer 11, 7-48.

Walter, H., 1971, Ecology of tropical and subtropical vegetation, Oliver \& Boyd Edinburgh.

Wardell, A., Nielsen, T.T., Rasmussen, K. \& Mbow, C., 2004, 'Fire history, fire regimes and fire management in West Africa: An overview', in J. Godammer \& C. de Ronde (eds.), Wildland fire management handbook for sub-Sahara Africa, pp. 350-382, Global Fire Monitoring Center, Freiburg.

West, O., 1955, 'Veld management in the dry, summer-rainfall bushveld', in D. Meridith (ed.), The grasses and pastures of South Africa, pp. 624-636, Central News Agency Ltd., Johannesburg.

West, O., 1972, 'Fire, man and wildlife as interacting factors limiting the development of vegetation in Rhodesia', in Proceedings of the tall timbers fire ecology conference, 11, Tall Timbers Research Station, June 8-9, 1972, Tallahassee, FL, pp. 121-146.

Witt, A.B.R., Kiambi, S., Beale, T. \& Van Wilgen, B.W., 2017, 'A preliminary assessment of the extent and potential impacts of alien plant invasions in the Serengeti-Mara ecosystem, East Africa', Koedoe 59(1), 1-16. https://doi.org/10.4102/koedoe. v59i1.1426 